\title{
Does the Targeted Jobs Tax Credit Create Jobs at Subsidized Firms?
}

\author{
JOHN H. BISHOP and MARK MONTGOMERY
}

This paper uses the results of a survey of more than 3,500 private employers to determine whether use of the Targeted Jobs Tax Credit (TJTC) alters the level of a firm's employment and or whom the firm hires. We estimate that each subsidized hire generates between.13 and 3 new jobs at a participating firm. Use of the program also appears to induce employers to hire more young workers (age 25 and under). Our results suggest, however, that at least 70 percent of the tax credits granted employers are payments for workers who would have been hired even without the subsidy. Such payments represent mere transfers to employers.

\section{Introduction}

For more than a decade federal employment policy has included provisions for subsidies to employers who hire welfare recipients or people who fall into certain other categories of disadvantaged workers. The most prominent of these subsidies is the Targeted Jobs Tax Credit (TJTC). Until the 1986 Tax Reform Act, the TJTC program offered employers a tax credit of 50 percent of the first-year wages up to $\$ 6,000$, and 25 percent of second-year wages up to $\$ 6,000$ for hiring any worker certified to be eligible. Currently the program offers 40 percent of wages up to $\$ 6,000$ during the first year. Eligible workers include economically disadvantaged ex-offenders, the vocationally rehabilitated handicapped, and recipients of Aid for Families with Dependent Children (AFDC) and/or general assistance. Though use was initially slight, the scale of the program has been rising, so that by the mid-eighties nearly 700,000 workers were being subsidized under the program.

The purpose of targeted employment subsidies is to increase employment of eligible workers. The subsidy can accomplish this by inducing firms to create new jobs (expand employment) that are then filled by targeted workers, and/or by encouraging firms to hire targeted workers to fill slots normally occupied by noneligible workers. In practice, a firm that receives a TJTC subsidy may do neither. The firm may simply be claiming a tax credit for an employee who would have been hired even without the subsidy. The purpose of this paper is to determine the extent to which receiving tax credits for hiring TJTC eligibles represents each of the following three components: (a) net job creation, (b) replacement of nontargeted workers with targeted ones, or (c) receipt of a subsidy for a worker who would have been hired in any case. No previous study has 
attempted to make this measurement. ${ }^{1}$ Yet the issue is important for policy makers who clearly prefer expansion of employment (a) to merely making transfer payments to employers (c).

This study is conducted using a survey of more than 3,400 employers specifically designed to address the issues described above. To determine whether TJTC induces firms to expand employment we estimate the impact that hiring TJTC-subsidized workers has on employment growth. The periods of time for which we have data are 1981 and part of 1982. We then examine whether TJTC alters who the firm hires. Ideally, this would be accomplished by estimating the impact of TJTC use on the proportion of targeted workers in the firm's work force. Because firms generally don't know how many of their workers meet TJTC's complicated eligibility requirements, however, our survey used the proportion of young workers (under 25) as a proxy for the proportion of targeted workers.

This paper is organized as follows. The first section describes the employer survey used in this study. The second section specifies the model of employment growth used to determine whether use of TJTC causes net job creation at the firm. The third section presents the empirical results for the employment growth effect of TJTC. The fourth section presents estimates of the impact of TJTC on the proportion of young workers at the firm. The fifth section summarizes and draws conclusions.

\section{Data}

Our data are drawn from a survey of more than 3,400 business establishments conducted in two waves. The first wave was carried out in the first quarter of 1980 by the Institute for Research on Poverty of the University of Wisconsin under the auspices of the Department of Labor. (Westat Inc. did the actual interviewing.) The second wave, of 3,412 of the original firms, was conducted by the National Center for Research in Vocational Education of the Ohio State University (NCRVE) in 1982. (The Gallup Organization did the interviewing.) The establishments surveyed were located in a set of 28 geographic sites. The sites overrepresented the Southeast, especially the Gulf Coast, and underrepresented the Northeast. The probability that a given firm at a given site would be sampled varied directly with the size of the firm. The NCRVE Survey provides data on employer use of TJTC programs in 1980, 1981, and early 1982. It also contains data on firms' use of programs under the Comprehensive Employment and Training Act (CETA) and the Job Training Partnership Act (JTPA) for the calendar year 1980 and the period from January 1980 to the interview date in early 1982.

Table 1 provides some summary statistics on the rates of use of TJTC by employers in our sample. These participation rates are not representative of those of the general population of firms. Because the first wave of the NCRVE survey (in 1980) informed respondents about the existence of these programs, familiarity with TJTC

\footnotetext{
1 Burtless (1985) presents experimental evidence that programs like TJTC may actually reduce the employment of targeted workers by stigmatizing them in the eyes of potential employers. This suggests that even if the current study finds that employers who hire targeted workers are creating jobs for them, it will not guarantee that the overall effect of the program is to increase their employment.
} 
TABLE 1

Participation in TJTC by Size of Establishment

\begin{tabular}{|c|c|c|c|c|c|c|c|c|}
\hline & & \multicolumn{5}{|c|}{ Number of Employees } & \multirow{2}{*}{$\begin{array}{l}\text { Total } \\
\text { Weighted } \\
\text { by Size }\end{array}$} & \multirow{2}{*}{$\begin{array}{c}\text { Total No } \\
\text { Weighted } \\
\text { by Size }\end{array}$} \\
\hline & & $1-9$ & $10-49$ & $50-99$ & $100-499$ & $500+$ & & \\
\hline 1 & Percent received TJTC in $1980^{a}$ & 38 & 46 & 73 & 51 & 294 & 146 & 43 \\
\hline 2 & $\begin{array}{l}\text { Percent received TJTC be- } \\
\text { tween Jan and Sept } 1981^{\text {a }}\end{array}$ & 2.6 & 44 & 99 & 198 & 475 & 21.3 & 35 \\
\hline 3 & $\begin{array}{l}\text { Percent received TJTC be- } \\
\text { tween Sept } 1981 \text { and Apr } \\
1982^{a}\end{array}$ & 23 & 28 & 82 & 179 & 349 & 161 & 27 \\
\hline 4 & $\begin{array}{l}\text { TJTC-subsidized employees in } \\
1980 \text { as \% of employment }\end{array}$ & 7 & 6 & 7 & 02 & 29 & & 10 \\
\hline 5 & $\begin{array}{l}\text { TJTC-subsidized employees }{ }^{\mathrm{b}} \text { in } \\
1981 \text { as } \% \text { of employment }\end{array}$ & 4 & 5 & 7 & 04 & 54 & & 18 \\
\hline
\end{tabular}

${ }^{a}$ Rows 1,2 , and 3 are weighted by employment in 1980 and the inverse of the probability of selection bData are for the first 9 months of calendar year 1981 
among respondents in the second wave was about 75 percent. ${ }^{2}$ We believe this to be a higher rate of familiarity than would be observed in the general population of firms.

Columns 1,2, and 3 present participation rates by establishment size for three periods: 1980, the first nine months of 1981, and for the period from September 1981 to the interview date in 1982, respectively. The period January-September 1981 is separated from the rest of 1981 because the rules for certifying eligibles changed in September 1981. After that time eligible workers could be certified only on or before the first day of work, and cooperative education students were no longer eligible unless they were disadvantaged. This rule change disallowed the retroactive certification that had previously been widely observed among participating firms. Overall utilization rates in our sample were under 5 percent for all periods. Larger firms were much more likely to use the program than were small firms. This is consistent with findings from the first wave of the survey (Bishop and Montgomery, 1986). Note that the rule change in September 1981 lowered participation rates for establishments in all size categories.

\section{The Impact of TJTC on Employment}

In this section, we present an empirical model of the impact of TJTC on the total employment level of firms that get a subsidy. Programs such as TJTC fall under the general heading of targeted marginal employment subsidies. They are "targeted" because they subsidize only workers in certain demographic categories. They are "marginal" because only additional workers are subsidized, not those already employed before the start of the program. The theoretical effects of marginal employment subsidies, both targeted and nontargeted, have been analyzed in a number of works by Bassi (1985), Layard and Nickell (1980), Perloff (1982), Bishop and Wilson (1982), and Montgomery and Wilson (1985). A subsidy like TJTC can influence total employment at a firm by causing labor to be substituted for other factors of production (the substitution effect) and/or by increasing total output (the output effect).

The output effect of an employment subsidy occurs if reduced cost can lead to a price reduction, thereby increasing quantity of the product demanded. Bassi (1985) argues that a marginal subsidy targeted to a relatively small demographic group is likely to have a very minor effect on output of the firm. The substitution effect associated with an employment subsidy can increase total employment in two ways. First, it can cause the firm to substitute labor for capital. Second, it can cause the firm to substitute less productive targeted workers for more productive nontargeted workers. Even with a fixed output level such substitution could raise total employment.

In spite of its theoretical potential for raising employment, there are good reasons to hypothesize that a firm may hire a relatively large number of TJTC-subsidized workers without actually creating new jobs. TJTC is not a true marginal subsidy of the type described in the theoretical literature; it is actually a "recruitment" subsidy. This means that a firm need not expand its complement of targeted workers in order to obtain a

2 About 17 percent of the establishments interviewed in the first wave were familiar with TJTC We expect that interviewing these firms in 1980 may have increased the proportion of them using the program in 1982, but we see no reason to expect that it would distort the relationship between usage and employment growth Having informed the firms earlier should not bias the coefficient of TJTC use in the growth models. 
subsidy, as it would under a true marginal subsidy. It need only hire a new targeted worker, even one who merely replaces a nontargeted worker. The elasticity of substitution of targeted for nontargeted workers may, therefore, be very high. With high substitutability the employment gain per TJTC hiring may be very close to zero.

The specification of the growth equation. The discussion above suggests the null hypothesis that hiring TJTC-subsidized workers does not influence an establishment's employment level. Empirically estimating the effect of TJTC on the level of a firm's employment is difficult, however. Employment level is determined by numerous factors that are difficult to observe and control for, factors such as relative input prices and technology. If these factors are relatively stable over a short time interval, however, they have little or no impact on the growth of employment during that interval. This implies that we can estimate a model of employment growth that excludes these factors with only minimal risk of omitted variable bias. For this reason, we chose to estimate the effect of the TJTC program on a firm's employment growth rather than its employment level. Our model mimics the approach taken by Perloff and Wachter (1979) in assessing the employment impact of the New Jobs Tax Credit of 1977.

To develop this model, we begin by assuming that the level of a firm's employment at a point in time, $E_{t}$, is related to the number of subsidized workers in its work force, $\mathrm{TJTC}_{t}$, plus a vector of other characteristics, $\mathrm{X}_{\mathrm{t}}$. For the moment we let the relationship be linear.

$$
\mathrm{E}_{81}=\alpha+\beta \mathrm{TJTC}_{81}+\gamma \mathrm{X}_{81}+\varepsilon
$$

where all values are measured at the end of the subscripted year, and $\varepsilon$ is an error term- $\varepsilon$ $\sim \mathrm{N}\left(0, \sigma_{\varepsilon}\right) . \mathrm{TJTC}_{81}$ is defined here as the stock of subsidized workers at the end of 1981 . As a proxy for this stock, we use the number of subsidized hires made during $1981 .^{3}$ If the subsidized workers were simply hired to fill slots that would normally go to nonsubsidized workers, or if the firm claims a credit only for workers it would have hired anyway, then $\beta=0$.

As stated above, instead of estimating equation (1), which would require a substantial complement of $\mathrm{X}$ variables, we use a model of the change in employment. If we assume no structural change in $\alpha, \beta$, or $\gamma$ between 1980 and 1981, then from (1) it must be the case that

$$
\begin{aligned}
& \left.\underline{\mathrm{E}}_{81}-\mathrm{E}_{80}=\beta \underline{\left(\mathrm{TJTC}_{81}\right.}-\mathrm{TJTC}_{80}\right)+\gamma\left(\underline{\mathrm{X}}_{81}-\mathrm{X}_{80}\right)+\mathrm{w}, \\
& \text { E } E \text { E }
\end{aligned}
$$

where $\mathrm{E}$ is the average of $\mathrm{E}_{80}$ and $\mathrm{E}_{81}$, and $w \sim \mathrm{N}\left(0, \sigma_{\mathrm{w}}\right){ }^{4}$ In fact, however, we prefer not to assume that $\beta$ is stable between 1980 and 1981. The change in rules disallowing

3 The number of subsidized hires m 1981 will understate the stock of TJTC-subsidized workers if many of those hired between January 1980 and January 1981 are still with the firm Given high turnover among workers from targeted populations, however, many workers hired more than a year before would have left the firm, and any who remained would be subsidized at only half the original rate.

4 Because we observe both positive and negative growth rates in our sample, the assumption that the error in the growth equations is approximately normal seems justified Nevertheless, that fact that about 30 percent of the establishments were clustered at zero growth could call this assumption into question. 
retroactive certification and disqualifying cooperative education students makes structural stability unlikely. Therefore, we estimate a model that includes separate measures of usage for 1980 and 1981 (as a proportion of employment).

$$
\mathrm{G}_{81}=\underline{\mathrm{E}}_{81}-\mathrm{E}_{80}=\beta_{\mathrm{E}} \underline{\mathrm{TJTC}} \underline{81}=\beta_{\mathrm{E}} \frac{\beta_{\mathrm{TJTC}}}{\mathrm{To}}+\gamma \mathrm{Z}+\mathrm{w},
$$

where $Z$ is a vector of variables designed to capture the determinants of employment growth. The vector $Z$ imitates the set of variables used by Perloff and Wachter (1979). $Z$ contains a long list of control variables from the first and second waves of the survey, including measures of changes in demand conditions, factors influencing labor turnover, and an array of other employer characteristics. The full list of variables is described in appendix $\mathrm{A}$.

It is clear in equation (3) that if the effect of TJTC on employment was positive and stable between 1980 and 1981, then

$$
\beta_{81}=-\beta_{80}>0
$$

That is, because it is the change in TJTC use that affects the change in employment, entering current and past usage into the model separately should cause past usage to have a negative $\operatorname{sign}^{5}$. The absolute value of $\beta_{80}$ is a measure of the effect of TJTC on employment in 1980.

To disentangle the effects of the rule change we include regressions that measure $\mathrm{TJTC}_{81}$ for two alternative periods: the first eight months of 1981 and the 15- to 20month period from December 1980 to the interview date. (The $Z$ vector is adjusted accordingly.)

The final specification of the employment growth equation includes one modification from equation (3) -we relax the assumption that the effect of TJTC on employment is linear. A few very small firms have very large ratios of TJTC hires to employment. We hypothesize that the subsidy has a diminishing effect on growth as the ratio of subsidized to total employment rises. When subsidy usage represents a very large share of the firm's employment an additional hire is more likely to represent a windfall to the employer than a new job induced by the program. To allow for this nonlinearity the marginal impact of TJTC usage on growth is assumed to be a step function that has a discontinuity at $\mathrm{TJTC}_{81} / \mathrm{E}$ equal to .5 . (The decision to use .5 as a cutoff, though somewhat arbitrary, seemed a reasonable choice. ${ }^{6}$ ) It is hypothesized that the coefficients

\footnotetext{
5 Because the dependent variable in equation (3) is a percentage rate of growth, the residual variances of this model are likely to be larger for small establishments than for larger establishments To correct for possible heteroskedasticity, a version of equation (3) was estimated using weighted least squares The weights were constructed by regressing the squared OLS error on the $\log$ of establishment size Neither the coefficients on the key subsidy variable nor their significance levels appreciably changed when the observations were weighted.

${ }^{6}$ More formally, because we are using a spline, we include two TJTC usage variables one equal to TJTC-certifications/employment up to half of employment (mm [TJTC81/E, 5]) and one equal to TJTC-certifications/employment above half of employment (max $(\mathrm{TJTCgl} / \mathrm{E})-5,0] \mathrm{A}$ spline was used instead of a quadratic in order to avoid multicollineanty in the 2SLS models
} 
on the upper portion of the splines will be closer to zero than will the coefficients on the lower portion of the splines.

Regression results for employment growth. Columns 1, 2, and 3 in Table 2 report the results of OLS estimation of alternative forms of equation (3). Columns 1 and 2 relate to employment growth from $12 / 80$ to $12 / 81$. Column 3 represents the period from $12 / 80$ to the interview date. Because TJTC use is likely to be correlated with participation in the on-the-job training programs, the models in Table 1 also control for use of the CETA and

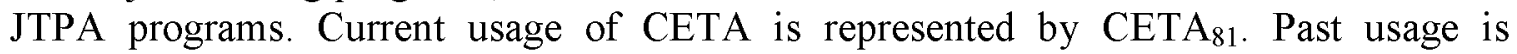
represented by $\mathrm{CETA}_{80}$ (a dummy) and $\mathrm{CETA}_{79}$, which contains all subsidized hires in 1979 including those for CETA, TJTC, and the Work Incentive Tax program (WIN). (In 1979 most subsidized workers were hired through CETA.) What this means is that the CETA $_{79}$ variable is measured with some error. Still, because use of TJTC and CETA are likely to be correlated, we need to control for CETA use to avoid having its influence bias the TJTC coefficients.

As expected, the results in columns 1,2, and 3 in Table 2 give estimates of $\beta_{81}$ and $\beta_{80}$ that are opposite in sign but close in absolute value. The coefficients on the lower portions of the splines are significant in almost all cases. The absolute values for both $\beta_{81}$ and $\beta_{80}$ are centered around .3 , and $\beta_{80}$ has the expected negative sign. These values imply that for every ten subsidized hirings up to half of employment, approximately three new jobs are created. The coefficients on the upper portions of the splines are close to zero and insignificant for all TJTC variables. The CETA variables also show statistical significance though their coefficients are small.

The potential endogeneity of usage. Because firms with high employment growth will have more job openings that might potentially be filled with TJTC-eligible workers, use of the subsidy may be endogenous. In this case the OLS coefficients on TJTC81 and CETA81 will be biased upward. To cope with the potential endogeneity, equation (3) was reestimated using two stage least squares (2SLS) ${ }^{7}$

Because the problem of endogeneity of usage was anticipated when the survey was designed, a great deal of thought was put into the development of questions that would provide a set of instruments for a 2SLS model of employment growth. The key was to obtain measures of variables that would influence TJTC hirings but not employment. Earlier studies have found that a firm's decision to participate in a subsidy program is significantly influenced by personal contacts about TJTC from local program administrators (Bishop, 1985; Bishop and Kang, 1986; and Bishop and Montgomery, 1986). Such contacts should have no exogenous impact on employment growth, however. Therefore, the survey contained a set of questions about personal contacts and other questions specifically designed to produce instruments for a 2SLS model. Bishop (1985) found that the effect of a personal contact on the decision to participate in TJTC depended on a number of establishment characteristics such as the number of employees, previous subsidy use, proportion of young workers at the firm, and others. These characteristics were interacted with the contact variables to expand the set of instruments. A detailed discussion of the set of instrumental variables is provided in appendix B.

\footnotetext{
7 Another potential source of bias in the OLS models is any unobserved firm characteristic that influences both the likelihood of using TJTC and employment growth The standard way of treating this problem is to replace the program participation variable with its predicted value, which is what the 2SLS models do
} 
TABLE 2

Effect of TJTC on Employment Growth at Subsidized Firms

( $t$-statistics in parentheses)

\begin{tabular}{|c|c|c|c|c|c|c|}
\hline & 1 & 2 & 3 & 4 & 5 & 6 \\
\hline $\begin{array}{c}\text { Method } \\
\text { Time Interval }\end{array}$ & $\begin{array}{c}\text { OLS } \\
12 / 80-12 / 81\end{array}$ & $\begin{array}{c}\text { OLS } \\
12 / 80-12 / 81\end{array}$ & $\begin{array}{c}\text { OLS } \\
12 / 80- \\
\text { Interview }\end{array}$ & $\begin{array}{c}\text { 2SLS } \\
12 / 80-12 / 81\end{array}$ & $\begin{array}{c}\text { 2SLS } \\
12 / 80- \\
\text { Interview }\end{array}$ & $\begin{array}{c}\text { OLS } \\
12 / 80-12 / 81 \\
\text { (New/Hires) }\end{array}$ \\
\hline \multicolumn{7}{|l|}{$\mathrm{TJTC}_{81} / \mathrm{E}$} \\
\hline Up to 5 & $\begin{array}{l}334^{* *} \\
(20)\end{array}$ & $\begin{array}{l}216 \\
(14)\end{array}$ & $\begin{array}{l}308^{* * *} \\
(23)\end{array}$ & $\begin{array}{l}894^{\mathrm{b}} \\
(10)\end{array}$ & $\begin{array}{l}908^{\mathrm{b}} \\
(11)^{8}\end{array}$ & $\begin{array}{l}066^{c} \\
(88)\end{array}$ \\
\hline Above 5 & $\begin{array}{c}-055 \\
(5)\end{array}$ & $\begin{array}{c}-043 \\
(4)\end{array}$ & $\begin{array}{c}-048 \\
(7)\end{array}$ & $\begin{array}{l}-615^{b} \\
(10)\end{array}$ & $\begin{array}{l}-770^{\mathrm{b} *} \\
(19)\end{array}$ & - \\
\hline $\mathrm{TJTC}_{80} / \mathrm{E}$ & - & - & - & $\begin{array}{r}-013 \\
(30)\end{array}$ & - & $\begin{array}{l}-063^{c} \\
(126)\end{array}$ \\
\hline Up to 5 & $\begin{array}{l}-250^{*} \\
(19)\end{array}$ & $\begin{array}{l}-251^{* *} \\
(21)\end{array}$ & $\begin{array}{l}-372^{* * *} \\
(22)\end{array}$ & - & - & - \\
\hline Above 5 & $\begin{array}{l}022 \\
(8)\end{array}$ & $\begin{array}{l}049 \\
(7)\end{array}$ & $\begin{array}{l}076 \\
(7)\end{array}$ & - & - & - \\
\hline $\mathrm{CETA}_{81} / \mathrm{E}>0$ & - & $\begin{array}{l}092^{* *_{a}} \\
(41)\end{array}$ & $\begin{array}{l}058^{* a} \\
(19)\end{array}$ & - & - & - \\
\hline $\mathrm{CETA}_{80-81} / \mathrm{E}$ & - & - & - & $\begin{array}{c}-390 \\
(93)\end{array}$ & $\begin{array}{r}-583 \\
(98)\end{array}$ & $\begin{array}{r}046 \\
(28)\end{array}$ \\
\hline Up to 5 & $\begin{array}{l}086 \\
(10)\end{array}$ & - & - & $\begin{array}{l}758^{\mathrm{b}} \\
(11\end{array}$ & $\left.\begin{array}{rl}1 & 14^{b} \\
(1 & 18\end{array}\right)$ & $\begin{array}{r}-079 \\
(34)\end{array}$ \\
\hline $\mathrm{CETA}_{80} / \mathrm{E}>0$ & - & $\begin{array}{l}007^{a} \\
(4)\end{array}$ & $\begin{array}{l}-030 \\
\left(\begin{array}{ll}1 & 1\end{array}\right)\end{array}$ & - & - & - \\
\hline $\mathrm{CETA}_{79} / \mathrm{E}>0$ & $\begin{array}{l}-085^{*} \\
\left(\begin{array}{l}1 \\
1\end{array}\right)\end{array}$ & $\begin{array}{l}-094^{*} \\
\left(\begin{array}{l}2 \\
2\end{array}\right)\end{array}$ & $\begin{array}{l}-162^{* * *} \\
(28)\end{array}$ & $\begin{array}{l}-134^{*} \\
(19)\end{array}$ & $\begin{array}{l}-261^{* * *} \\
(260)\end{array}$ & $\begin{array}{l}-111^{* * *} \\
(221)\end{array}$ \\
\hline $\mathbf{R}^{2}$ & 086 & 094 & 107 & 086 & 095 & 114 \\
\hline Sample & 3255 & 3255 & 3255 & 3115 & 3115 & 2298 \\
\hline
\end{tabular}

aThese are $0-1$ varıables for whether a subsıdızed worker was hıred

bVariable is replaced by its predicted value

"Variable is a ratio of subsidized hires to new hires

${ }^{*}{ }^{* *}$, and ${ }^{* * *}$ indicate significance at the 1,05 , and 01 levels, respectively 
The 2SLS results are presented in columns 4 and 5 of Table 2. The coefficients on $\mathrm{TJTC}_{81}$ up to 50 percent of employment are very large but not statistically significant. The coefficients on the upper portion of the splines are negative, and in one case significant. The 2SLS coefficients imply that ten TJTC hirings produce about nine additional jobs at the firm. Unfortunately, these numbers are not plausible. The coefficients on CETA $_{81}$ are actually negative, though not significant.

Given the assumed positive feedback of employment growth on subsidy usage, reestimation of the employment growth equation using 2SLS should have lowered the coefficient on TJTC use. Instead, point estimates got larger and the statistical significance declined. Our interpretation of these results is that despite careful efforts to design questions that would provide an appropriate set of instruments, those instruments obtained were apparently not sufficient to capture the structural relationships with the necessary degree of precision. ${ }^{8}$ We believe that this may prove to be an inescapable problem with all nonexperimental evaluations of employment training programs.

An alternative to $2 S L S$ : Subsidized hires as a proportion of all new hires. In view of the unsatisfactory nature of the 2SLS results, a second approach to the problem of simultaneity bias was employed. Simultaneity causes the estimates of $\beta_{81}$ obtained from the OLS estimation of (3) to be positively biased. The alternative approach is to provide another estimate that is also biased, but biased in the opposite direction. If the TJTC usage variable can be reconfigured so that the simultaneity biases its estimated effect toward zero, we may at least be able to place a lower bound on the program's true impact on employment at the firm (while the OLS results will represent an upper bound). We accomplish this by replacing the ratio of subsidized hires to employment with the ratio of TJTC-certified workers hired in 1981 to all workers hired in 1981. If employment growth has a strong positive effect on the number of new hirings, using new hirings in the denominator of the TJTC-use variable should build in a negative bias in its coefficient. The results of regressions using this approach are reported in column 6 of Table 1 . Because a splined model gave a large negative coefficient on the upper portion of the spline, the model presented constrains the upper portion to be zero.

The coefficients on TJTC use as a proportion of new hires have a low level of significance. However, the implied impacts of TJTC on employment growth are considerably more reasonable than those for the 2SLS results. Transforming the coefficient on $\mathrm{TJTC}_{81}$ in column 6 to reflect jobs created per certification (by multiplying by the mean ratio of employment to certifications, which is 2 in our sample) the newhires model implies that the number of added employees per TJTC certification is .13. ${ }^{9}$

8 An alternative explanation, suggested by a referee, is that the instruments are unable to explain the arbitrary break in the spline. This view is consistent with the results of alternative runs in which we included a 2SLS model that predicted only the probability of using TJTC The usage coefficients were positive and significant at the .01 level, with $\beta_{81}=46$ and $\beta_{80}=-148$ These results imply an implausibly large effect for participating in TJTC

9 To convert the coefficient on the effect of an increase in certifications as a proportion of new hires to the effect of certifications as a proportion of employment, we multiply the coefficient in model 6 by the ratio of employment to certifications via the following equation (where CERTS refers to certifications, EMPchg to employment change, and EMP to employment)

$\frac{\Delta\left(\frac{\text { EMPchg }}{\text { EMP }}\right)}{\Delta\left(\frac{\text { CERTS }}{\text { EMP }}\right)}=\frac{\Delta\left(\frac{\text { EMPchg }}{\text { EMP }}\right)}{\Delta\left(\frac{\text { CERTS }}{\text { New Hires }}\right)} * \frac{\left(\frac{\text { CERTS }}{\text { New HireS }}\right)}{\left(\frac{\text { CERTS }}{\text { EMP }}\right)}=\beta_{\mathrm{n}}^{\mathrm{NH}} * \frac{\text { EMP }}{\text { New Hires }} *\left(\frac{\% \Delta \text { CERTS }-\% \Delta \text { New Hires }}{\% \Delta \text { CERTS }-\% \Delta \text { EMP }}\right)$ 
This is about 40 percent of the impact estimated from the first model in Table 2. It represents, we believe, a reasonable lower bound on TJTC's impact on employment at participating firms.

To summarize the regression results: we find some evidence that TJTC does induce participating firms to expand employment, though this conclusion is somewhat tentative. What is not tentative is our conclusion that at best, seven out of ten TJTC payments are for workers in jobs that would have existed absent the subsidy. This does not imply, however, that those seven payments are useless in terms of advancing the goals of the program - the subsidy may have induced the establishments to hire TJTC eligibles for jobs that would otherwise have gone to nontargeted workers. In the next section, therefore, we explore the effect of TJTC on who gets hired.

\section{The Effect of TJTC on the Proportion of Young Workers}

Even a targeted employment subsidy that does not create jobs overall may still fulfill its primary policy objective by creating jobs for targeted workers. To accomplish this, it must have some impact on whom the firms decide to hire. In this section we examine whether TJTC altered who was hired by estimating its impact on the proportion of young workers at the firm. Ideally, we would like to observe the impact of hiring TJTC eligibles on the proportion of targeted workers at the firm, but employers are unlikely to know how many workers meet TJTC's complicated eligibility requirements. Instead of asking about the number of eligibles, therefore, the survey asked about an easily identifiable population into which about 86 percent of TJTC eligibles fall: workers under the age of 25 .

The 1982 NCRVE Survey asked each establishment (1) what proportion of its work force was under 25 currently, and (2) what proportion was under 25 two years ago. We employ two alternative specifications in estimating the impact of TJTC on this proportion. First, we regress the current proportion of young workers on a set of variables including the past proportion of young workers, a TJTC-use variable, and other firm characteristics. As an alternative, we also estimate a model of the change in the proportion of youth over the previous two years with past and current TJTC use as independent variables. As above, for the change model we expect a positive coefficient on $\mathrm{TJTC}_{81}$ and a negative coefficient on past usage. In this case, however, past usage is CETA 79 , which includes subsidized hirings from all programs.

The other independent variables in these equations differ only slightly from those included in the growth models. A run including the full set of independent variables appears in appendix A. One important difference, however, between the employmentgrowth models and proportion-youth models is the inclusion of employment growth itself as an independent variable in the latter. Rapidly growing firms should be more willing to select younger, less experienced workers to fill vacancies. We expect, therefore, that the coefficient of employment growth will be positive in the proportion-youth models.

The TJTC usage variable, $\mathrm{TJTC}_{81}$, in the proportion-youth models includes one important modification from the growth models. Firms can deliberately select targeted

where ${ }_{\text {s: }}^{\mathrm{F}}$ is the coefficient from model 6 in Table 2 The ratio of employment to new hires in our sample is 2 Because CERTS is generally small relative to new hires and employment, we assume that the percentage change in certifications will dominate the percent changes in new hires and employment and the last term on the right will be close to 1 


\section{TABLE 3}

Impact of Targeted Employment Subsidies on the Share of the Work Force Under Age 25

(t-statistics in parentheses)

\begin{tabular}{lcc}
\hline \hline & Level Model & Change Model \\
\hline TJTC $_{81}{ }^{a}$ & & $114^{* * *}$ \\
Up to 5 & $120^{* * *}$ & $(212)$ \\
Above 5 & $(21)$ & \\
CETA $_{79}$ & 007 & \\
Employment Growth $1980-82$ & $(2)$ & $-069^{* *}$ \\
Proportion under age 25 in 1980 & $-07^{*}$ & $(2.03)$ \\
$\mathrm{R}^{2}$ & $(-18)$ & $078^{* * *}$ \\
Sample & $(52)$ & $(5.8)$ \\
\hline
\end{tabular}

a Variable represents hirıng of workers known to be eligible at the time of hiring

${ }^{*},{ }^{* *}$, and ${ }^{* * *}$ indicate significance at the 1,05 , and 01 levels, respectively 
workers over nontargeted workers only if the former are recognized as eligible at the time the hiring decision is made - a fortuitous discovery of the eligibility of a recent hire should have no direct impact on youth's share of employment. Our usage variable, therefore, is not the proportion of workers who are eligible, but only the proportion known to be eligible at the time they were hired. ${ }^{10}$

Estimation results for the proportion of young workers. The estimation results for the two models of youth share of employment are presented in Table 3. The TJTC 81 variable is highly significant in both the level model and the change model. Furthermore, the positive and significant effect of employment growth on the youth share implies that TJTC has both a direct and indirect impact on the proportion of young workers at the firm. To gain some sense of the magnitude of these effects, we use an example. Consider a firm with 100 workers, 27 percent of whom are youth (our sample mean). Using the coefficient from column 1 in Table 3, hiring ten TJTC eligibles raises the proportion of youth to 28.2 percent directly. But, according to Table 2, these hirings also increase growth of employment by 3 percent, which raises youth's share by another 2 percent (that is, by $3 \mathrm{x}$ .067). This further increases the proportion of young workers to 28.4 percent. These calculations imply that the ten subsidized hires open 2.4 jobs for young workers (that is, $.284 * 103-27$ ) in a firm of 100 workers. ${ }^{11}$

What do the coefficients in Table 3 imply about the extent to which TJTC hires cause intrafirm displacement of nontargeted workers? The above example suggests that the ten subsidized hires generated about three new jobs and that 2.25 of these went to youth, creating an additional .75 jobs for adults. Taken at face value these numbers would absolve TJTC of causing significant displacement of adult workers. They imply that the program may even increase adult employment slightly by causing firms to expand. This calculation, of course, uses our most optimistic finding about the effect of TJTC on the subsidized firm's employment. But even if using TJTC were to have a zero impact on a firm's employment, the ten subsidized Wrings in our firm of 100 workers would displace 1.82 adults. This is still a reasonably small displacement effect. Our overall conclusion, therefore, is that any intrafirm displacement of adults caused by TJTC is likely to be fairly minor.

\section{Conclusions and Discussion of Policy Implications}

This paper used the results of a unique survey of employers to estimate (a) the extent to which using the Targeted Jobs Tax Credit (TJTC) induced subsidized employers to expand employment, and (b) the extent to which TJTC use caused the participating firm to hire more targeted workers. Our best estimate implies that no more than three new jobs are created at a participating establishment for every ten subsidized hirings that establishment makes. Our estimates of TJTC's impact on youth's share of employment suggest that TJTC use does significantly increase the hiring of targeted workers.

\footnotetext{
10 As in the growth models, our proxy for the proportion of known-to-be-eligibles at the firm is the number hired in the relevant time

period
11 These estimates are rough for two reasons First, the proportion of workers under 25 is a crude proxy for the proportion of targeted labor-young workers form only a portion of the targeted population (in our sample, about $85 \%$ ) Second, in the proportion-youth equation we used the hiring of known-to-be-eligibles while in the growth equation we used all subsidized hirings. The effect of all subsidized hirings on the proportion of young workers might be smaller than that used above to calculate the displacement
} 
Furthermore, these additional targeted workers do not appear to displace nontargeted adults (though they may displace nontargeted youth).

Perhaps the most interesting implication of our results is that when the government grants a tax credit for these ten subsidized hirings, at least seven of those tax credits are paid for job slots that would have existed even without the subsidy. Policy makers might be pleased nevertheless if those other seven hirings represent a transfer of jobs from nontargeted workers to targeted ones. But our results imply otherwise. We find that ten hirings create less than 2.5 jobs for young workers. If targeted youth are displacing nontargeted youth, our results may understate the program's potential to create targeted jobs. Still, we are led to conclude that the great majority of claims for tax credits are for workers who would have been hired even in the absence of the subsidy. These are simple transfer payments to employers.

What do our results imply about the cost of job creation under TJTC? Program data for fiscal 1985 (the most recent available) indicate that the TJTC program made tax expenditures of about $\$ 505$ million for 621,889 certifications. This gives a cost per TJTC certification of about $\$ 812$. Using this measure of certification cost, our most optimistic results about the employment effect of TJTC imply that in our sample the cost of creating a job through TJTC was $\$ 5,270$. Our more pessimistic results (using the last model in Table 2) suggest a cost of $\$ 11,581$ per job created. The lower figure is fairly consistent with similar estimates made elsewhere in the literature. For example, Bassi's (1985) simulation model predicts that jobs created through a targeted marginal subsidy will cost between $\$ 2,198$ and $\$ 5,708$ apiece. Bishop (1981) estimates the cost of jobs created by the New Jobs Tax Credit at between $\$ 2,000$ and $\$ 5,500$ per job. The higher of our estimates, $\$ 11,581$ per job created, is about twice the upper bound of the Bassi and Bishop estimates. Yet we think this estimate is closer to the true cost. ${ }^{12}$

It was recognized that problems caused by possible simultaneous equations bias in our estimates require that our results be viewed with some caution. However, given the effort that went into designing the NCRVE survey specifically to address the issues raised in this paper, we believe that our estimates are not only the best available measures of TJTC's impact on participating firms, but the best that are ever likely to be produced for the time period studied. The fact that we obtained measures of the level of usage of the subsidy gives our study more power than similar attempts to measure the impact of employment subsidies. For example, in their study of the New Jobs Tax Credit of 1978, Perloff and Wachter (1979) were able to test only whether having "heard of" that program caused firms to grow more rapidly. At the very least we have been able to set a reasonable upper bound on the effect of a subsidized hiring on a firm's total employment; it creates between .13 and .3 jobs. Placing the impact within this narrow a range provides information that should prove useful in the design of employment policy.

A final caveat should be offered about the employment effects discussed in this paper. We have estimated the impacts of TJTC on employment at participating firms only. These effects may be offset to some degree by reductions in employment in competing firms, or in firms producing capital goods (see Perloff, 1982). Such generalequilibrium considerations are beyond the scope of this paper, however.

\footnotetext{
${ }^{12}$ We calculate these values by multiplying the coefficients on the upper and lower portions of the splines in the relevant model by the mean sample ratio of certifications to employment above and below 5, respectively This gives the estimate of jobs created per employee at the firm We divide this value into the subsidy payments per employee at the firm, using $\$ 812$ as our estimated payment per certification
} 


\section{Appendix A: Independent Variables in the Employment Growth Equation}

The specification of the percentage employment growth equation used in this study parallels that used by Perloff and Wachter (1979) in examining the employment impact of the 1977-78 New Jobs Tax Credit - a nontargeted marginal employment subsidy. Perloff and Wachter, using a U.S. Census survey of establishments, regressed the percentage change in employment on (1) percentage change in nominal sales, (2) a set of four size of-establishment dummies, (3) a set of three regional dummies, (4) a set of one-digit industry dummies, and (5) dummies for which tax form the firm used (an indicator of type of proprietorship). Their key program variable was a dummy for whether the firm knew about the New Jobs Tax Credit.

Our estimation of the employment growth equation improves upon that of Perloff and Wachter in having more detailed data on establishments and a larger sample. First we included a set of variables designed to capture exogenous changes in demand conditions. In this category we included the percentage change in real sales over the previous two years. This variable may be endogenous, but, like Perloff and Wachter, we lacked an appropriate set of instruments with which to use an instrumental variables model. We also include a proxy for previously anticipated changes in demand conditions: the change in employment from 80 to 82 anticipated by the establishment at the time of the firstwave interview.

A second set of variables relates to the establishment's experience with labor turnover (all taken from the first wave of the survey). The rationale here is that holding constant the conditions of product demand and labor supply, turnover may affect employment growth by dictating the number of hires required to maintain a given size of the work force. Finally, we included a set of more general characteristics of the establishment and its work force such as size, the proportion of skilled workers, the proportion unionized, and others. One variable that our data set lacked was a direct measure of average wages of workers at the establishment. Our survey provided information on wages only for the last worker hired. As a measure of the establishment's wage position relative to other establishments, we regressed the wage of the last hired worker on a vector of characteristics of the worker and the job for which he was hired. The error from this regression was used as a measure of whether the establishment paid higher wages (a positive error) or lower wages (a negative error) than other establishments hiring this type of worker in a similar job.

We also included detailed sets of industry and location dummies.

A sample run for the models of employment growth and proportion of young workers appears in Table Al.

\section{Appendix B: Discussion of the Variables Used as Instruments in 2SLS Models}

The variables employed as instruments were those that were observed to be important in determining whether an establishment participated in the TJTC program at all (by hiring at least one subsidized worker) in studies by Bishop (1985), Bishop and 
TABLE A1

Sample Runs with Full Sets of Independent Variables

\begin{tabular}{|c|c|c|c|c|c|c|}
\hline \multirow{2}{*}{$\frac{\text { Varıable }}{\text { Program Variables }}$} & \multicolumn{2}{|c|}{ Mean (std dev) } & \multicolumn{2}{|c|}{$\begin{array}{c}\text { Employment } \\
\text { Growth (t-stat) } \\
12 / 80 \text {-Interview }\end{array}$} & \multicolumn{2}{|c|}{$\begin{array}{l}\text { Proportion } \\
\text { Young (t-stat) }\end{array}$} \\
\hline & & & & & & \\
\hline \multicolumn{7}{|l|}{$\mathrm{TJTC}_{81} / \mathrm{E}$} \\
\hline Up to 5 & 0088 & $(05)$ & 308 & $(229)$ & 120 & $(210)$ \\
\hline Above 5 & 0312 & (08) & -048 & $(-67)$ & 007 & ( 19) \\
\hline \multicolumn{7}{|l|}{$\mathrm{TJTC}_{80} / \mathrm{E}$} \\
\hline Up to 5 & 007 & (04) & -372 & $(-221)$ & - & \\
\hline Above 5 & 002 & ( 06) & 076 & $(75)$ & - & \\
\hline $\mathrm{CETA}_{81}>0$ & 038 & ( 19) & 058 & $\left(\begin{array}{l}1 \\
87\end{array}\right)$ & - & \\
\hline $\mathrm{CETA}_{80}>0$ & 045 & (21) & 030 & $(105)$ & - & \\
\hline $\mathrm{CETA}_{79}>0$ & 023 & ( 10$)$ & -168 & $(-277)$ & -07 & $(-181)$ \\
\hline \multicolumn{7}{|l|}{ Change in Demand } \\
\hline$\triangle \mathrm{EMP}$ & -028 & (40) & - & & 069 & $\left(\begin{array}{ll}5 & 22\end{array}\right)$ \\
\hline$\Delta \mathrm{EMP}>0$ & 091 & ( 22) & - & & -02 & $\left(\begin{array}{ll}-1 & 04\end{array}\right)$ \\
\hline Expected $\% \Delta$ Unit Sales & 042 & (27) & 386 & 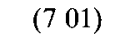 & 015 & ( 56) \\
\hline Actual $\% \Delta$ Unit Sales $>0$ & 084 & (23) & -266 & $(-428)$ & 018 & $(60)$ \\
\hline Expected $\triangle$ EMP 1980-82 & 1073 & $(4827)$ & 001 & $(523)$ & - & \\
\hline \multicolumn{7}{|l|}{ Turnover Variables } \\
\hline New Hire Rate 1979 & 089 & (12) & -008 & $(-13)$ & - & \\
\hline Quit Rate 1979 & 048 & (08) & - & & -046 & $\left(\begin{array}{lll}1 & 00\end{array}\right)$ \\
\hline Fire Rate 1979 & 015 & ( 05$)$ & - & & 086 & (1 25) \\
\hline $\begin{array}{l}\text { Layoff Criterion (seniority }=1, \\
\text { productivity }=0 \text { ) }\end{array}$ & 41 & (27) & 007 & (32) & - & \\
\hline Flexibility to Fire 1979 & 4965 & $(500)$ & - & & 000 & $\left(\begin{array}{ll}1 & 13\end{array}\right)$ \\
\hline $\begin{array}{l}\text { Length of Probation Period for } \\
\text { New Hires }\end{array}$ & 281 & $\left(\begin{array}{ll}1 & 24\end{array}\right)$ & 027 & $(271)$ & -006 & $(-1.26)$ \\
\hline No Probationary Period & 24 & ( 43) & -08 & $(266)$ & - & \\
\hline \multicolumn{7}{|l|}{ Other Employer Characteristics } \\
\hline Est SIZE (ln) 1980 & 293 & $(144)$ & -067 & $(958)$ & 012 & $(442)$ \\
\hline Est SIZE $50^{\mathrm{a}}$ & 25 & $(63)$ & 05 & (3 41) & - & \\
\hline Est SIZE/Firm SIZE & 48 & $(118)$ & -004 & $(-.95)$ & 003 & $(133)$ \\
\hline Residual Wage (ln) & 00 & $(32)$ & 057 & $\left(\begin{array}{ll}3 & 24\end{array}\right)$ & -020 & $(-236)$ \\
\hline Machınery Cost (ln) & 170 & $(149)$ & 011 & (293) & -002 & $\left(\begin{array}{ll}-1 & 12\end{array}\right)$ \\
\hline Proportion Part-tıme & 18 & $(27)$ & -.011 & $(-51)$ & 009 & $(85)$ \\
\hline Proportion Unıonized & 10 & (28) & -.009 & $(-180)$ & -010 & $(-92)$ \\
\hline$\Delta$ Proportion Unıonized & -000 & (05) & - & & 012 & $(72)$ \\
\hline $\mathbf{R}^{2}$ & & & 11 & & 72 & \\
\hline
\end{tabular}

${ }^{a}$ Also included were dummies for industry and location 
Kang (1986), and Bishop and Montgomery (1986). The participation studies cited indicate that the most important of the instruments is personal contacts about TJTC or CETA that were initiated by agencies outside the firm. (An offer to refer TJTC-eligible workers doubles the probability that a firm participates in the program [Bishop, 1985].) Dummy variables were created for initial contacts made by, respectively, a government agency, a trade association, a local business organization, or some other agency.

Dummies were also created for whether the employment service had initiated a contact to offer subsidy-eligible referrals, and whether there was more than one such contact. All dummies were denned separately for TJTC and CETA.

Bishop (1985) found that whether an outside contact caused the firm to participate in TJTC depended on a variety of firm characteristics. Consequently another set of instruments was created by interacting the dummies described above with the following firm characteristics: log of establishment employment, dummies for previous use of subsidy programs, membership in a local business organization, presence of a personnel office at the establishment, share of 1980 employment under age 25, length of training period for new hires, whether the firm has a probationary period for new hires, and the $\log$ of the length of that period. Other instrumental variables were (1) dummies for previous use of subsidy programs, (2) previous use of the employment service, (3) membership in a local business organization, (4) the perceived amount of paperwork required to obtain an OJT contract, (5) a variable measuring negative attitudes toward government, (6) knowledge of the CETA program, (7) whether the firm fired anyone during the fourth quarter of 1979 (a proxy for flexibility in terminating unwanted employees), and (8) measures of the 1979 layoff rate, quit rate, and induced quit rate, respectively.

In total the structural models of participation contained 33 variables that were not in the structural model of growth and 28 variables that were not in the structural model of the 1981 new hire rate. The $\mathrm{R}^{2}$ for the reduced form models predicting the TJTC usage variable ranged from .074 to .091 .

\section{REFERENCES}

Bassi, Laurie J 1985 "Evaluating Alternative Job Creation Strategies " Economic Inquiry 23 (October) 671-90 1981 "Employment in the Construction and Distribution Industries The Impact of the New Jobs Tax Credit " In Studies in Labor Markets, edited by Sherwin Rosen Chicago University of Chicago Press

Bishop, John H 1985 Targeted Jobs Tax Credit Findings from Employer Surveys Prepared for the Department of Health Services under grant \#DHHS113A-83 Columbus National Center for Research in Vocational Eduction, Ohio State University September

Bishop, John H, and Suk Kang 1986 "Multivariate Models of Employer Use of TJTC " In The Effects of TJTC on Employer Columbus National Center for Research in Vocational Education, Ohio State University

Bishop, John H , and Mark Montgomery 1986 "Evidence on Firm Participation in Targeted Employment Subsidy Programs " Industrial Relations 25 (Winter) 56-64

Bishop, John H, and Charles Wilson 1982 "The Impact of Employment Subsidies on Firm Behavior " In Jobs for the Disadvantaged, edited by Robert Haveman and John Palmer Washington, DC: Brookings Institution 
Burtless, Gary. 1985 "Are Targeted Wage Subsidies Harmful Evidence from a Wage Voucher Experiment" Industrial and Labor Relations Review 39 (October) 105-14

Haveman, Robert, and John Palmer, eds 1982 Jobs for the Disadvantaged Washington, DC Brookings Institution

Layard, K., and S Nickell 1980. "The Case for Subsidizing Extra Jobs " The Economic Journal 1 51-53

Montgomery, Mark, and Charles A Wilson 1985 "On the Dynamic Response of a Firm to an Employment Subsidy with a Fixed Threshold " Journal of Economic Dynamics and Control (December) 405-22

Perloff, Jeffrey 1982 "Micro and Macro Effects " In Jobs for the Disadvantaged, edited by Robert

Haveman and John Palmer Washington, DC Brookings Institution

Perloff, Jeffrey, and Michael Wachter 1979 "The New Jobs Tax Credit An Evaluation of the 1977-78 Wage Subsidy Program" American Economic Review (May):173-79 